\title{
A Critical Analytic Discussion of Massive Curriculum Pedagogy Comparable to Holly Books-Towards ICTs Strategies
}

\author{
M. Ziad Hamdan ${ }^{1 *}$ (iD) \\ 1,2 Hamdan Academy for Higher Education Online, United Arab Emirates
}

*Corresponding author: hamdanacademy@gmail.com

\section{Abstrak}

Pedagogi kurikulum besar-besaran (MCPs) merupakan masalah metodologis abadi sekolah di seluruh Era Umum. Teknik penelitian deskriptif kausal-komparatifl ex-post facto dan Pendekatan Pengembangan Tindakan digunakan untuk memahami realitas masalah secara objektif, menelusuri hubungan sebab-akibat antara faktor-faktor MCP, dan membangun solusi efektif untuk masalah penelitian MCP. Penalaran logis semantik dari hasil menunjukkan hubungan yang kuat antara MCP, pengajaran Holly Books (H.B.s) dan Model Pendidikan Pabrik 1800+ dalam berbagi pembelajaran dan instruksi kelompok besar yang luas. Bahkan pedagogi kurikulum mengambil dari $H$. Bs pembelajaran wajib selain metodologi pengajaran yang masif. Apa yang mengganggu di sini adalah pedagogi negatif ini bertentangan dengan kesejahteraan peserta didik di Era Info Global dan keragaman sumber TIK yang tersedia untuk sekolah. Peserta didik pada dasarnya tidak memiliki bakat yang identik, kebutuhan pengetahuan prioritas, kecepatan berpikir dan pencapaian, jadwal, dan ruang hidup untuk belajar dan sekolah. Mempertimbangkan hasil penelitian dan prinsip pragmatis 'tidak ada yang dapat menanggapi keragaman kecuali keragaman', Penulis menawarkan strategi tandingan ("Sekolah tanpa Gagal") yang sesuai dengan rekan-rekan yang dipersonalisasi, berbasis TIK, dan kolaboratif, memungkinkan $97 \%$ pelajar untuk mencapai kurikulum "campuran-digit" yang dipelajari.

Kata kunci: Konten Kurikulum Suci, Kitab Suci, Multi Learning Streaming

\section{Abstract}

Massive curriculum pedagogies (MCPs) represent an everlasting methodological problem of schooling throughout the Common. Era. Descriptive causal-comparative/ ex-post facto research techniques and Action Developmental Approach were used to objectively comprehend the problem's realities, trace the cause-effect relations between MCPs' factors, and build effective solutions to the MCPs' research problem. The semantic logical reasoning of results showed strong linkages among the MCPs, the Holly Books' (H.B.s) teaching and the Factory Educational Model 1800+ in sharing extensive large groups learning and instruction. Even curriculum pedagogies took from H.Bs the compulsory learning besides the massive teaching methodology. What is disturbing here is these negative pedagogies are against the welfare of learners in the Info Global Age and the wide diversity of ICTs' sources available to schooling. Learners have by nature no identical aptitudes, priority knowledge needs, thinking and achievement speeds, timelines, and live spaces for learning and schooling. Considering the research results and the pragmatic principle of 'nothing can respond to diversity except diversity', the Author offered a countering strategy ("Schools without Flunking”) merited with personalized, ICTs' based, and collaborative peers, enabling $97 \%$ of learners to achieve the studied "blend-digit" curricula.

Keywords: Teachers' Readiness, Online Learning, Online Teacher

$\begin{array}{ll}\text { History: } & \text { Publisher: Undiksha Press } \\ \text { Received : January 19, } 2021 & \text { Licensed: This work is licensed under } \\ \text { Revised : March 03, } 2021 & \text { a Creative Commons Attribution 3.0 License } \\ \text { Accepted : April 04, } 2021 & \text { CC () () } \\ \text { Published : April 25, 2021 } & \end{array}$

\section{INTRODUCTION}

Pedagogy is a general operational framework for learning and teaching a piece of knowledge (Feladi et al., 2020; Suciu \& Mata, 2011). It refers to the deliberation process of needed developments in a given culture and society. Hence, pedagogy has three basic components: curriculum, or the content of learning and teaching; methodology, or the way in which both are done; and techniques for socializing children in the repertoire of cognitive, affective and psychomotor skills required for successful functioning in society that education is designed to promote (Brown, 2001; Junaid \& Baharuddin, 2020). Several cultural factors and public events had intervened to block the reformation of schooling and school systems around the World, perpetuating the conventional teacher-centered society approach and large groups teaching. It started early in the written human civic BCE history of Babylon Scribers, 
the Pharos Clergymen, Confucius China, the Sophists 500 BCE, the Plato Academy 487 B.C., and the Church preachers, 100- 1800 A.D. All these pioneers and knowledge sources had perpetuated society through teaching generations what served best the community purposes, regardless of how gifted reformers they were at their times.

Current massive schooling and educational systems are too old, overly outdated, and severely unproductive. One educator expressed deep dissatisfaction with conventional schooling by stating: "Our current education system based itself on outdated concepts leftovers from the agricultural and industrial ages." He added, "In the Information Age, information - not raw materials and physical labor-is power" (Koehler \& Mishra, 2006; Schwab, 2016). The long years of didactic education of children had been reinforced by Gutenberg's massive book production 1500+ A.C, and the infusion of the Factory Educational Model (FEM) in schooling 1800s- 1990+. However, the initiation of Digital Information Highway 1995+ had steamed ICTs developments and dissemination in Western communication and education. Even though schooling entered the Digital Age by the 21st Century, schools of western systems continued generally with the extensive large group methods with limited ICTs applications to give an impression of modernity (Dennis, 2017; Jan, 2017; Yusof et al., 2012).

Developing countries' schools, on the other hand (as this Author observed), are not only persisting on the past, rather are regressive and lenient towards learners and teachers' backward practices, values and techniques such as cheating, plagiarism, grade inflation, passing flunked or non-attended courses, negligent learning and teaching, and valuing schooling as a low priority. Further, the positive effects of 'Glocalization' based heavy use of ICTs and the rise of global digital communities have widely allowed free movement of information, innovations, commodities, services, and individuals. However, some side effects had emerged such as 'social exclusion' and 'digital divide' which indicate "a deprivation of factors and processes that emphasize material, psychological, social and digital needs" (Pradana et al., 2020; Trisiana, 2020). Having indicated above two shortcomings, the hope is still live for intellectual, digitally skilled, and esteemed young men and women to overcome these hurdles within a limited optimal time (Knapp, 2014; Lase, 2019). In brief, the above deficiencies had culminated in the (FEM) during the 1800s. It led also to the rise of powerful centralized education systems where teachers directly manipulated the learners' population and the learning processes. Lecturing, repeating, and reciting teaching and learning continued up to the beginning of the 21st Century where the FEM in schooling started tapering down (Koshy et al., 2011; Willems \& Carina, 2012).

This article focuses on the adverse side effects of the extended period of large groups' education where no progress was observed, especially in "Third World Countries." The massive educational pedagogies (the first problem of the article) kept the status quo of education at its slightest degree possible in most related human concerns from thinking and pioneering, schooling, ways of living, businesses, to ambitions for the future. While there are abundant ICTs developments, meaningful records of informed integration in education appeared very limited. The situation seems paradoxical. While indicating significant ICTs developments brought by the First Information Revolution at the beginning of the $21 \mathrm{st}$ Century, insufficient use of ICTs in "Blend-Digit" pedagogies, accompanied with much propaganda and empty talks about fake or unreal ICTs applications in education, which represents the second problem of the article. The third problem facing ICTs reformation of schooling is its scattered, unorganized efforts of scholars and high-tech specialists of the "Blend-Digit" approach. Field tech professionals and specialists are not doing enough to activate ICTs role into advancing education, where several promotional events are available to help so; such as webinars, online seminars, conferences, and clubs such as digital alliances, 
digital school societies, local and glocal digital communities, digital regional societies, a coalition of 'glocal schools, and "Blend-Digit" school leagues.

\section{METHODS}

The research methodology applied in this article is the descriptive 'Causal Comparative/ Ex Post Facto techniques and the Action developmental' method. This multi research approach focuses on tracing the cause-effect relationships of schooling problems, and how to encounter the weakening causes to develop the concerned factors for effective education like the curriculum, instruction, learning, the standards, the procedures, and learners' satisfactions. It involves searching the problem past realities, analytic evaluation of event data, critical reflection on the status quo, and proposing a developmental action plan for changes in the practice (Creswell, 2015). The main questions of the article are: what are the factors that negatively affected the curriculum pedagogies? And what is the "Blend-Digit" alternative strategy to reform the analog curriculum large groups' methods?

\section{RESULTS AND DISCUSSION}

\section{Results \\ The Factory Model and Feature Practices Related to Curriculum Pedagogies}

School systems had copied the massive mode of education after the factory model (FM) of the industrial factories throughout 1750- 1850 AD. Thus, the educational factory model appeared from its beginning 200 years ago, a gigantic unified, standardized production of learners. Children under this model are merely analog 'human materials' processed through 'factory classrooms' for 'educational manpower harvests' qualified primarily for societal, economic, administrative, and maintenance purposes, with rare or no considerations to learning individuation, self-initiation, or innovation. Most school reform efforts are variations of factory model schooling. 'Core practices and structures of the factory model schooling are still governing the analog curricula, through grouping learners by age, distributing them into segregated buildings, standardizing texts, measuring learners' achievement for purposes of comparison, and standardizing teacher work'. Factory modeled schools, as any other extensive large groups of teaching and learning, when are organized efficiently as could be, may maximize quantitated production, but far from qualitative graduates.

Shortcomings through persisting core practices and structures of the factory model, which are still used today in the twentieth of 21 st Century, including "bias grouping of learners by age, distributing them into container buildings, standardizing curriculum, measuring learner achievement for purposes of comparison, and standardizing teacher work." While the strategic aims are the preparation of citizens or intellectual development had competing values; Reformers of social efficiency saw the main charge of schools is preparing generations for economic roles and maintaining social order. The standards movement that began in the 1990s still drives school reform and perpetuates the practice of the factory model through its high concentration on societal welfare testing. The current movement and academic studies of Education Economics had started and flourished during the Printing Revolution 1500+ A.C. and the practices of the Factory Model schooling 1800+. The massive learning-teaching halls, which appeared during 1800-1950 A.C. and its large group classrooms residuals were persisting up to the beginning of the current 21 st Century, represent in effect the philosophy and policy of Education Economics.

However, there are three main criticisms of the 'FM': First, "this 'FM' instruction is highly inequitable, reproducing social stratification based on race and social class. Second, its 
curriculum is a standardized-based white upper-middle-class worldview that limits perspectives, funds of knowledge, and intellectual inquiry and delves the diverse learners in schools. Third, its orientation around compliance with and maintaining the status quo, rather than social transformation, despite using the term "reform." More instructional implications of the factory educational model are its overwhelming practice of "massive didactic pedagogy. "Teacher-centered society" plays the role of direct senders "orators and sole sources of curriculum knowledge." On the other hand, learners through the "massive didactic pedagogy" are merely "passive listeners" along the school's daily class periods. They pass through different shifts of pedagogies and didactics, which are contrasting in meaning and action, as explained below: Pedagogy covers why, how, talks of education, and thinks about the curriculum, the values, the visions of education, and more. Pedagogy is comparable to methodology in education, which converts analog schooling facts into actions. Didactics focus on how. It is a technique more focusing and direct. FEM massive methodology is a technique, more than a pedagogy.

\section{Negative Consequences of the Factory Model Massive Techniques on Curriculum Pedagogies}

The failure of educational developments and the massive curriculum pedagogies didn't stem from religions per se; instead, in the corrupted official authorities and shortsighted political leaderships; Who were directly beyond the massive massacres of peoples and cities' destruction of the annexed territories and the extensive backward massive learning -teaching and local schooling. Since early history, this Author observes the "satanic psychology" of Athens politicians, when accused Socrates of spoiling the moralities of Athenian youth. They faked the death ruling of Socrates' 384 B.C. Further, the Crusaders 1096-1291 who falsified news of locals' intolerance against pilgrimage visitations to holy places. Expeditions were launched, massacres were committed, and put the lives of east Mediterraneans in extreme horror and jeopardy, including massive shutoff or unstable schooling.

The Muslim Mongols' 1258 who also wrecked everything in Baghdad, the Capital City of the Abbasids Caliphate. They committed massive massacres of Baghdad's population from up the Caliph to the ordinary people walking on the streets; burned all books, manuscripts, records and libraries. The Ottomans' annexation of 1516-17 A.D. of the Arab Mediterranean region led to the brutal, backward occupation of the whole territory that ended 1918 as the Allies at the First World War defeated Turkey. The new European powers followed suit using disguised reasons for annexing vast lands in old and new Worlds for imperial, political, and economic reasons. These events and many more had slowed down the reforming educators and endeavors to take significant steps in furthering education. This neutral status quo continued until the end of the twentieth Century where the "Info Super High Way" was launched around 1995 in western communication and education systems.

Further, religious rituals require large groups' recitations and repetitions on Sundays or other holidays (as large groups' faith classrooms). Its contents are predetermined by a metaphysical God or by human reformers of 'human-made faiths', e.g., Buddhism, Hinduism, Taoism, Atheism, Sikhism, Mormonism, and Baha'i. The learning-teaching contents are unified and unchangeable over time. Contrary to the above sacred religious curricular contents (the Holy Books), curriculum and education contents in schools and universities at the "Blend-Digit" 21st century should be concerned with the development of diverse generations individually and peer groups, regarding age stages, growth-learning needs, education stages, socio-economic classes, socio-educational organizations such as the family, the school, the university, the hobbies, recreational clubs, the sports leagues, the fine art associations, and more. The above diverse 'Growth Needs' of generations, individuals and peer group learners necessitate extreme differentiation in quantity and quality of study 
contents, methodologies, environments, open sources, "Blend-digit" open schedules, and learners-centered schooling (Hamdan, 2021).

\section{Holly Books Contents-Different Significance Degrees of chapters and Verses, and Implications to Curriculum Pedagogies}

The contents of God's "Holly Books" are untouchable and ultimately crucial to the welfare of human lives. However, when one immerses in chapters and verse details, he or she becomes aware that a chapter in whole or in part, a Verse, or group of Verses are concerned with a specific life issue or need. These human interests range from absolute, which determine the psychosocial identity of a person or a community, as being Jews, Christians, or Muslims. This Author calls these unique contents priority, fundamental beliefs, or tenets as examples below. While the Hebrew Bible and the New Testament are closely related texts, the sacred scripture of Islam, the third Abrahamic faith, has generally been considered separately. However, religious scholar Reynolds, 2018 draws on centuries of Qur'ānic' and Biblical studies to offer rigorous and revelatory commentary on how these holy books are intrinsically connected. Reynolds demonstrates how Jewish and Christian characters, imagery, and literary devices feature prominently in the Qur'ān, including stories of angels bowing before Adam and of Jesus speaking as an infant. This vital contribution to religious studies features a complete translation of the Qur'ān along with excerpts from the Jewish and Christian texts. It offers a precise analysis of the debates within the communities of religious scholars concerning the relationship of these scriptures, providing a new lens through which to view the strong links that bond these three major religions.

The First Significance Degree of Tura's Content, the Determinants of Judaism Faith and Followers Identity. The fundamental teachings of Judaism are: There is only one God, and that God is Yahweh; God only created the universe, and only He controls it; God is spiritual and not physical; God is one whole complete being who wants people to do what is just and compassionate. The First Significance Degree of Bible's Content, the Determinants of Christian Followers Identity. The belief of: God the Father, Jesus Christ as the Son of God, and the Holy Spirit; The death, descent into hell, resurrection, and ascension of Christ; The Bible is inspired authoritative Word of God; The holiness of the Church and the communion of saints. Since the Bible chapters are what God wants us to know, we can rightly say that all topics are essential. But opinions are divided when it comes to choosing the most critical chapters in the Bible. For instance, someone says Matthew chapters 5, 6, and 7 are the three most important chapters in the Bible because they "are about the most concise description of how God wants people to live for that they could ever hope. This relative understanding of holy Bible content applies to the argument of the current article problem "the relativity of man-made- curriculum content."

\section{Consequences of the Holly Books Teaching on Curriculum Pedagogies}

The big massive pedagogic mistake as this author believes, committed by preachers of the three heavens' religions, Judaism, Christianity, and Islam; and human-made faiths, e.g., Hinduism, Buddhism, Jainism, Taoism, and Sikhism, goes back to the primary use of 'congregation oral method' (large audience). It took place in worshiping places like churches, synagogues, and mosques. Through this lecturing general method, other techniques are used, e.g., congregation reciting verses, demonstrations, memorizing individually and in groups, short lectures and presentations, storytelling drills, repetition, practical simulation, some discussions and simulations, forum, contextual teaching, reflections, group activities, small groups-preacher short interviews, and teaching practice (Aziz et al., 2016). Further, it is educationally meaningful to note two informed comments: First, The Religion teaching should avoid strict, corporal one-way pedagogy, focusing on memorizing faith facts and 
rituals without comprehending what they mean and how applying them in actual practices. Instead, religion pedagogy, like other meaningful academic and life domains such as almanac, space discoveries, digital information science, family organization, medical/health sciences, and nutrition; should rely heavily on interactive, and critical analytic discussions, opinion exchange, collaborative individual/small peer groups practices, mobile conferencing, e-chats, and "Blend-Digit" approaches.

Second, the massive curriculum content pedagogies had accrued from several unjustified factors and conditions. For examples: Conventional professionally outdated teachers: Firstly, were raised through strictly centralized Factory Model schooling, didactic educators and systems, especially in developing and underdeveloped countries. Secondly, teachers working for "Third World" systems lack the concept and practice of in-service training or continuing education. They are simply deprived of in-service training workshops or continuing education programs. Hence, their professional contemporary competencies could be at least possible levels. Teachers' lack of reformation attitudes towards schooling due to illiteracy in ICTs knowledge, values, and skills that made them unaware of belonging to learning generations in $21^{\text {st }}$ Century. So teachers tend not to bother due to feeling horrified of educational change related to technologies. As such, they feel more comfortable keeping the 'status quo of learning and teaching. Teachers' indifference towards the welfare of generations and schooling, which badly affects the quality of education. This cynical attitude reflects negative consequences on the concept and practice of 'Quality Citizen' (Hamdan, 2021). True' Quality Citizen' teacher has unconditional faith in fellow citizens, native 'home Land,' and civic glocal educational goals; regardless of miserable local economic and political shortcomings or the corruptions of negligent officials. The shallow professional competencies of conventional teachers make them readily falling into repairing weak incompetence through another weakness, which is embodied in the Factory Model and the Holly Books massive pedagogy. The next ICTs strategy "Schools without Flunking" is presented to enable 97\% of Learners achieve Studied Curricula (Hamdan, 2019).

It is sustainable strategy to achieving $97 \%$ of Learners the studied "BlendDigit" curricula. Massive schooling generally works like whole production factories. The standard curve and subjective norm-referenced achievement assessment principle do not guarantee learners' success in further studies or related job realities. The alternative objective measure adopted by the "SWF" is a criterion-referenced assessment that authenticates performance success based on actual field requirements. "Schools without Flunking" (SWF) is a "strategic inclusive quality education model for a sustainable glocal schooling." SWF is a contemporary "Blend-Digit" education approach that responds to each learner's needs, interests and hobbies. It allows learners to learn specific curriculum contents or the textbook, congruent with their aptitudes (particular intelligence) and the future work or profession desired for life (Hamdan, 2019). School curricula or texts are non-sacred by their rights. Therefore, all learners who are using the same academic content, language, design, digital forms, are not obliged to apply unified conventional whole analog, large group contents methodologies due to two reasons: first is, the "blend-digital" nature of the current Age; and the second is, the compelling learning strategies of the 21 st generations are learners-centered, individuation/small peer groups, self / collaborative projects, criterion-referenced, self-paced and multi achievement tracks. Continuing with traditional school methodology through the third Millennium is considered educationally futile due to the digital Info Age and accelerating ICTs developments are trending. The SWF disregarded the conventional 'Normal Curve' principles and practices of achieving students: $3 \%$ gifted, $13 \%$ superiors, $68 \%$ average, $13 \%$ below average, and 3\% borderline; into "Negatively skewed distribution" of higher achievement results (Figure 1): $97 \%$ of students succeed courses with grades A \& A+; $\mathrm{B}, \mathrm{B}+$ and $10 \%$ with $\mathrm{C}$. 


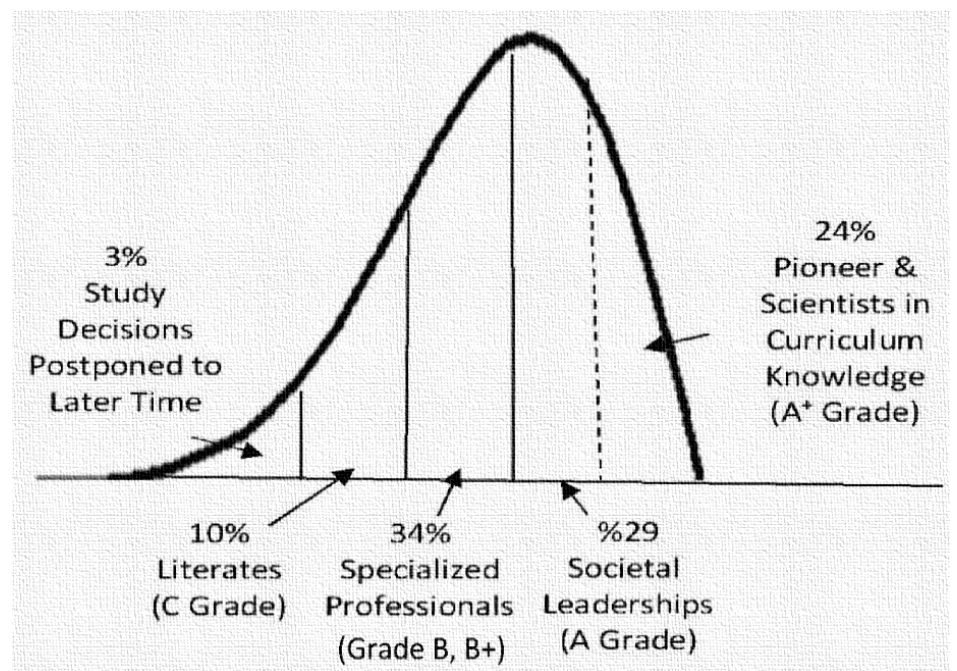

Figure 1. Negatively skewed distribution of higher achievement results due to applying SWF (Hamdan, 2019)

Governing principles and mechanisms of SWF, namely: SWF is learner-centered strategy from planning, development, designing learning activities, learning, achievement, to student self and peer assessment; SWF allows students to work collaboratively on group projects, case studies, presentations, demonstrations, and reports utilizing cross-studied subjects or disciplines; Utilizes heavily diagnostic analytic and formative assessments with a final central summative exam at the end of senior high school. Students are ready to go to college for academic specialization; SWF provides equal opportunities for all students for high-quality education; SWF is highly responsive to students learning needs for individuation and small group collaboration. SWF teachers are professionally well qualified, preferably with masters, are coordinators, non-directive guiding academic counselors, and experts in the knowledge and pedagogy of their specialized fields.

\section{Technological, methodological, and logistical constituencies for implementing SWF in Schooling.}

Successful implementation of SWF Strategy in schooling is dependent upon the following procedures: Internet availability $24 / 24$ in all schools where countries are hosting the SWF Project. Internet is maintained by enlarging and building upon the already existed local telecommunication companies; Transforming the curriculum or textbook content into four streams for learning. Individual students and self-selected small groups will be ready to assume blended and online-paced learning for selected achievement grades: C, B, or A): academic literate-c (general knowledge of the subject); specialist workers- B (e.g., teachers, engineers, chemists, or social workers and others), societal leaders-A, or academic pioneers$\mathrm{A}+$ (e.g., reformers, thinkers, scientists, inventors, and theorists). The next level of learning focuses on subjects' commons to which students move individually and in small groups to learn about their interests or work needs. While this element, coupled with the core, determines the academic nature of the curriculum, it prepares learners for professional and specialist roles; Availability of competent, equipped teachers with ICTs knowledge, skills, and methodologies. This professional concern could efficiently achieve through intensive training and workshops.

Availability of familiar non-directive teachers with ICTs culture are accustomed to the realities of SWF application in schools utilizing online micro learning; Providing students with up-to-date digital equipment for learning. Such tools as laptops, tablets, and mobiles, 
free or highly discounted, will ease practicing the SWF and succeeding in "blend-digital" learning-instructional methodology; Availability of skilled technicians for computers, laptops, tablets, mobiles, and internet maintenance; Transforming conventional paper analog school environments into open digital and blended learning and teaching where connected classrooms, WI FI equipment, students' carrels, blended libraries, information, and learning centers.

\section{Discussion}

In lieu of the ICTs first revolution at the beginning of $21^{\text {st }}$ century, school curricula and college courses will never continue into paperbound studying media as the case of 500 years ago since German Guttenberg invented the paper printing press 1445 CE. A coalition of national "Blend-Digit" schools and an alliance of 'glocal' continental "Blend-Digit" schools could rise for accomplishing the learners-centered- growth needs. However, professional plans, and meticulously prescribed mentoring-action programs should operate side by side to steer these 'could be' ICTs organizations. The overwhelming developments of ICTs and the deep penetrations of digital technologies in every aspect of human life, communications, administrations, economics, and education; have made it possible for the ICTs to enforce a profound change in the nature of education media and negate the analog 'paper' forms of education, e.g. curricula, texts, books, manuals, guides and programs for the sake of digital and blended alternatives (Chikasanda et al., 2013; Flowerdew, 2005). However, the analog and digital forms in future schooling and higher education will never reach zero or $100 \%$, since there will be a percentage of learners, young and adults who prefer paper modes and others who disfavor the digitals.

Moreover, it is predicted in the near future (3-5 years from 2021) that most nations and education systems (around 80\%) throughout the globe will turn into blended and digital communities in education and ways of life. On another hand, marginal states and underdeveloped countries will continue educationally dormant, experiencing no or limited changes or progresses due to several backward economic, educational, political, wide spread corruptions, and "low Brand Uneducated Leaderships" instabilities. Consequently, teachers are generally unqualified professionals; curricula are physically non-existent and study texts are sometimes missing most of the school year; Support services are nominally existent; and educational facilities resemble physically barely the standard concepts of schools and classrooms. The tyranny beyond the downward of the marginal states and underdeveloped countries, as this Author noticed that as much they are suffering from poverty, deprivation, illiteracy, under nutrition and bad health; as much their political, military and economic leaders are: The richest among all others on the Globe, and more mentioned millionaires in world wealth journals such as Forbes, DOAJ, Los Angeles Business Journal, and Bloomberg Billionaires Index, The most corrupted among their local and glocal citizens. The least educated among country's citizens, The more doubted honesty of their wealth resources. The vaguer life is leading glocally. The less popular among fellow citizens.

\section{CONCLUSION}

Finally, curriculum pedagogies will be freed of the Factory Model and Holly Books descriptive massive teachings (HBTs), due to two reasons. One, these massive approaches don't respond through didactic recitation to generations' needs for understanding the religions; and second, HBTs are contrary to the modes of current Global Digital Age. They are extremely outdated and non-responsive to the learning alternatives available to contemporary generations, e.g. individuation, collaborative peer groups, non-directive learners and the social psychology of inter-independent achievers. 


\section{REFERENCES}

Aziz, A. A., Ibrahim, M. A., Shaker, M. H., \& Nor, A. M. (2016). Teaching Technique of Islamic Studies in Higher Learning Institutions for Non-Arabic Speakers: Experience of Faculty of Quranic and Sunnah Studies and Tamhidi Centre, Universiti Sains Islam Malaysia. Universal Journal of Educational Research, 4(4), 755-760. https://doi.org/10.13189/ujer.2016.040412.

Brown, H. D. (2001). Teaching by principles: An interactive approach to language pedagogy. Longman.

Chikasanda, V. K. M., Otrel-Cass, K., Williams, J., \& Jones, A. (2013). Enhancing teachers' technological pedagogical knowledge and practices: A professional development model for technology teachers in Malawi. International Journal of Technology and Design Education, 23(3), 597-622. https://doi.org/10.1007/s10798-012-9206-8.

Creswell, J. W. (2015). Penelitian Kualitatif \& Desain Riset. Mycological Research, 94(4), 522.

Dennis, R. (2017). Preparing 21st Century Students for a Global Society: An Educator's Guide to the "Four Cs." National Education Association.

Feladi, V., Hendriyani, Y., Dewi, I. P., Darni, R., \& Verawardina, U. (2020). The Profile of Technological Pedagogical and Content Knowledge of Information and Communication Technology Teachers. Test Engineering \& Management, 83, 16661673.

Flowerdew, L. (2005). Integrating traditional and critical approaches to syllabus design: The 'what', the 'how'and the 'why?' Journal of English for Academic Purposes, 4(2), 135-147. https://doi.org/10.1016/j.jeap.2004.09.001.

Hamdan, Z. (2019). A Road Map for Prescribed" Blend-Digit" Personalized Learning-A Collaborated Responsive Approach to succeeding Generations in the Info Global Age. Universal Journal of Educational Research, 7(7), 1495-1508. https://www.academia.edu/download/64243873/UJER3-19513260.pdf.

Hamdan, Z. (2021). A Reforming Inclusive Quality Educational System for a Sustainable Glocal Learning-a Countering Paradigm to the Massive Backward Curriculum and instruction Pedagogies. Journal of Education, Society and Behavioural Science. http://www.sciencedomain.org/page/sciencedomain-ejournal-price-79-discount.

Jan, H. (2017). Teacher of 21st century: Characteristics and development. Research on Humanities and Social Sciences, 7(9), 50-54.

Junaid, R., \& Baharuddin, M. R. (2020). Peningkatan Kompetensi Pedagogik Guru melalui PKM Lesson Study. To Maega: Jurnal Pengabdian Masyarakat, 3(2), 122-129. https://doi.org/10.35914/tomaega.v3i2.413.

Knapp, C. E. (2014). Place-based curricular and pedagogical models: My adventures in teaching through community contexts. Place-Based Education in the Global Age, 2952. https://doi.org/10.4324/9781315769844-8.

Koehler, M. J., \& Mishra, P. (2006). Technological Pedagogical Content Knowledge: A Framework for Teacher Knowledge. Teachers College Record, 108(6), 1017-1054.

Koshy, K., Koroi, A., Netaf, N., \& Koya, C. F. (2011). Integrating sustainability into teaching and research at the University of the South Pacific to enhance capacity for the sustainable development of PICs. Journal of Social Sciences, 7(1), 6-12. http://repository.usp.ac.fj/id/eprint/4633.

Lase, D. (2019). Education and Industrial Revolution 4.0. Jurnal Handayani, 10(1), 48-62.

Pradana, L. N., Sholikhah, O. H., Maharani, S., \& Kholid, M. N. (2020). Virtual mathematics kits (VMK): Connecting digital media to mathematical literacy. International Journal of Emerging Technologies in Learning, 3, 234-241. https://doi.org/10.3991/ijet.v15i03.11674. 
Schwab, K. (2016). The Fourth Industrial Revolution: what it means, how to respond. World Economic Forum.

Suciu, A. I., \& Mata, L. (2011). Pedagogical Competences - The Key to Efficient Education. International Online Journal of Educational Sciences, 3(2), 411-423. https://www.acarindex.com/dosyalar/makale/acarindex-1423904375.pdf.

Trisiana, A. (2020). Penguatan pembelajaran pendidikan kewarganegaraan melalui digitalisasi media pembelajaran. Jurnal Pendidikan Kewarganegaraan, 10(2), 31-41. https://ppjp.ulm.ac.id/journal/index.php/pkn/article/view/9304.

Willems, J., \& Carina, B. (2012). Equity considerations for open educational resources in the Glocalization of education. Distance Education, 33(2), 185-199. https://doi.org/10.1080/01587919.2012.692051.

Yusof, K. M., Hassan, S. A. H. S., Jamaludin, M. Z., \& Harun, N. F. (2012). Cooperative Problem-based Learning (CPBL): Framework for Integrating Cooperative Learning and Problem-based Learning. Procedia - Social and Behavioral Sciences. https://doi.org/10.1016/j.sbspro.2012.09.649. 